\title{
Sleeping Disorders and Anxiety in Academicians: A Comparative Analysis
}

\section{Akademisyenlerde Uyku Bozuklukları ve Kaygı: Karșılaștırmalı Bir Analiz}

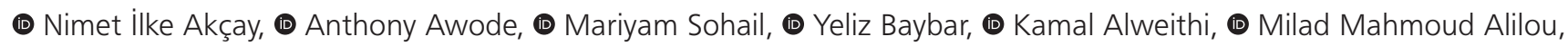 \\ (D) Mümtaz Güran
}

Eastern Mediterranean University Faculty of Medicine, North Cyprus, Turkey

\begin{abstract}
Objective: This study aims to examine the relationship between anxiety and sleep disorders and also to investigate the frequency of sleep disorders those with anxiety disorders among academicians who is a limited study group.

Materials and Methods: Two hundred and fifty academicians from different faculties across our campus participated in the study with a gender distribution of $47 \%$ males and $53 \%$ females. The study was conducted by a combined questionnaire which has four sections about (i) demographic information, (ii) sleep stages and sleep quality screening, (iii) scaling of sleep disorders and (iv) scale of anxiety.

Results: Anxiety in female and male participants was found to be $59 \%$ and $41 \%$ respectively. The total score of anxiety scale was positively correlated $(r=0.168, p<0.05)$ with the total score of sleep disorders scale. Total score of anxiety scale was negatively correlated $(r=-0.75$, $p>0.05$ ) with the total score of sleep quality. $51 \%$ of study group has insomnia which was found to be the most common sleep disorder whereas nightmare is the most prevalent sleep disorder for people who have anxiety problem.

Conclusion: Our findings are evidence that sleep disorders and anxiety in academicians are interrelated and academicians should be in a more stress-free working environment in order to increase efficiency.

Keywords: Academician, anxiety, sleep disorder, sleep quality
\end{abstract}

Öz

Amaç: Bu çalışma kaygı ve uyku bozuklukları arasındaki ilişkinin irdelenmesini ve kaygı bozukluğu olanlarda uyku bozukluklarının sıkığının kısıtı bir çalışma grubu olan akademisyenlerde incelenmesini hedeflemektedir.

Gereç ve Yöntem: Kampüsümüzdeki farklı fakültelerden 250 akademisyen \%47 erkek ve \%53 kadın cinsiyet dağılımı ile çalışmaya dahil edilmiştir. Çalışmada (i) demografik bilgiler, (ii) uyku evreleri ve uyku kalitesi taraması, (iii) uyku bozukluklarının ölçeklendirilmesi, ve (iv) kaygı ölçeği olmak üzere 4 bölümden oluşan birleştirilmiş bir anket formu kullanılmışıtır.

Bulgular: Kadın ve erkek popülasyonda kaygı sırası ile \%59 ve \%41 olarak belirlenmiş̧ir. Kaygı ölçeği puanlaması ile uyku bozuklukları ölçeği puanlaması arasında pozitif bir ilişki $(r=0,168, p<0,05)$ belirlenmiştir. Uyku kalitesi ölçeği toplam puanları ile kaygı ölçeği toplam puanları negatif ilişkili idi $(r=-0,75, p>0,05)$. Çalışma grubunun \%51'inde uykusuzluk problemi olduğu ve uykusuzluğun en sık uyku bozukluğu olduğu, kaygı problemi yaşayanlarda ise kabus görmenin en sık görülen uyku bozukluğu olduğu belirlenmiştir.

Sonuç: Bulgularımız akademisyenlerde uyku bozuklukları ve kaygının birbiri ile bağlantılı olduğuna ve verimin artması için akademisyenlerin daha stressiz bir çalışma ortamında olmaları gerektiğine kanıt oluşturmaktadır.

Anahtar Kelimeler: Akademisyen, kaygı, uyku bozukluğu, uyku kalitesi

\section{Introduction}

Sleep is a vital activity in every living organism, of which the disruption can lead to dire consequences. Having a good night sleep is important for optimal functioning of the body systems. On the contrary not having a good sleep can lead to certain diseases which can be characterized by abnormal sleep patterns that interfere with physical, mental, and emotional functioning. In other words, sleep disturbances are common conditions compromising health and longevity (1).
Anxiety is a general term for several disorders that causes nervousness, fear, apprehension and worrying (2). Interestingly, there is a relation between sleep deprivation and anxiety disorders (3). Neuroimaging and Neurochemistry studies suggest that a good night's sleep helps foster both mental and emotional resilience, while chronic sleep disruptions set the stage for negative thinking and emotional vulnerability (4). Furthermore, sleep disruption which affects levels of neurotransmitters and stress hormones, wreaks havoc in the brain, impairing thinking and emotional regulation (5). 
Those with sleeping disorders in addition to anxiety are at risk for heart disease, heart failure, irregular heartbeat, heart attack, high blood pressure, stroke, diabetes, and obesity (6). Anxiety disorders are considered as the most frequently occurring category of mental disorder in the general population, and epidemiological study estimates the lifetime frequency of anxiety disorders between $10 \%$ and $25 \%$ (7). Consequently, as much as one third of the adult population reports difficulty in sleeping and sleep disturbance is considered as the second most common symptom of mental distress (8). Anxiety and depression are among the factors that results in Insomnia as well $(9,10)$. Accordingly, it is reported that sleeping disorders might severely impair life quality and downgrade working efficiency (11). As a result, sleep problems can be strongly associated with anxiety problems in the general population. However, there is little research examining this relation in specific populations who are exposed to different stress levels.

This study, taking academicians as study subjects, aims to investigate the relationship between sleeping disorders and anxiety and to examine the frequency of sleeping disorders and anxiety in a stricken population of academicians which are assumed to be a stressful group.

\section{Materials and Methods}

\section{Participants}

A sample of 280 academicians from randomly selected faculties of our university was invited to participate in the study, 250 yielded to fill in our questionnaire, giving a participation rate of $89 \%$. Amongst the participants, $47 \%$ were males and $53 \%$ females. Data was collected through self-administered questionnaire regardless of ethnicity, nationality, race, gender or major. The distribution of participants according to their faculties and schools is as follows: english preparatory school (15.5\%); faculty of law (11.2\%); faculty of medicine $(10.4 \%)$; faculty of architecture (9.6\%); faculty of pharmacy (7.6\%); faculty of business and economics (6.0\%); faculty of engineering (14.8\%); faculty of arts \& sciences (8.0\%); school of foreign languages (11.3\%); faculty of tourism (3.6\%); faculty of communication (2.0\%).

\section{Measures}

In order to evaluate the perceived anxiety and sleeping disorders, four scales were used: Sleep Quality, Epworth Sleepiness scale, Sleep Disorder scales (Insomnia Severity index, SLEEP-50 Questionnaire, Sleep Apnea index) and Zung-self anxiety index (12-17).

In constructing the questionnaire, care was taken with phraseology, clarity and shortness of questions. It questioned whether or not the academicians experience anxiety related sleep disorders. It also helped us to obtain information about sleeping patterns and sleep quality of every individual.

\section{Procedure and Evaluation}

Questionnaires were distributed, and data was collected between February 15 and March 15 of 2016. The study protocol was approved by Eastern Mediterranean University Research and Publication Ethics Board. Participants were informed about the study prior to completing our questionnaire, and if they accepted to participate in this study, they signed consent forms. Participants were asked to complete the questionnaire individually in a day and to leave them the next day in the labelled box for questionnaires left at the secretary's office for every faculty. In addition, before being administered to the definitive survey population, the questionnaire was tested to ensure that there were no vague or misleading questions in the questionnaire.

\section{Statistical Analysis}

Participants were assured anonymity and the confidentiality of the data collected. For evaluation; descriptive statistics such as mean, frequency, percentages were calculated; and chisquare test and Pearson correlation were used for comparative statistics. P-values less than 0.05 were considered to indicate significant results.

\section{Results}

From the 250 participants, 123 were suffering from anxiety, and those who did not have anxiety were found to be 127 . In the anxiety stricken population of 123, 73 were females and 50 were males whereas in the non-anxiety stricken population of 127, males were 67 and females being 60 . Out of the 27 individuals who experienced nightmares in the general population, $63 \%$ suffered from anxiety. $60 \%$ of the bruxism experienced population suffered from anxiety, whereas anxiety rate for insomnia stricken population and sleep apnea stricken population were found to be $59 \%$ and $54 \%$ respectively (Table $1)$. Based on the chi-square test result $\left(\chi^{2}=4.061\right.$ and $\left.p=0.044\right)$, the relationship between anxiety and sleep disorders is found to be significant.

It was found that 129 of 250 participants (51.6\%) were suffering from one or more sleep disorder. Most prevalent sleep disorder was Insomnia followed by bruxism then nightmares and least common being sleep apnea (Table 1).

In our study, we also investigated the relationship between sleep disorders and most common complains of stressed people which are common pains and tiredness. For instance, those who suffered from a sleep disorder felt weak or got tired more easily as compared to those who didn't suffer from a sleep disorder. This relation was found to be significant $\left(\chi^{2}=15.406, p=0.002\right)$ (Figure 1). Also, study group with insomnia experienced significantly higher percentage of headache, back pains and neck pains as compared to the population without insomnia $\left(\chi^{2}=34.551, p<0.001\right)$ (Figure 2). Furthermore, it was found

\begin{tabular}{|l|l|l|l|l|l|l|}
\hline \multicolumn{2}{|c|}{ Table 1. Anxiety with gender and frequency of sleep disorders } \\
\hline \multicolumn{5}{|c|}{ Gender } & \multicolumn{5}{c|}{ Sleep Disorders } \\
\hline Male & Female & Nightmares & Bruxism & Insomnia & Sleep apnea & \\
\hline $117(47 \%)$ & $133(53 \%)$ & $27(10.8 \%)$ & $31(12.4 \%)$ & $51(20.4 \%)$ & $20(8 \%)$ & General population \\
\hline $50(41 \%)$ & $73(59 \%)$ & $17(63 \%)$ & $19(60 \%)$ & $30(59 \%)$ & $11(54 \%)$ & Anxiety (+) \\
\hline
\end{tabular}


that people are complaining from pains and tiredness for some of the time or never, not in a big portion of time.

Another finding was that, academic status is directly related with anxiety and good sleep. Anxiety was most common in instructors, assistant professors and senior instructors respectively. Similarly; instructors, assistant professors and senior instructors are having the poorest sleep experience respectively $\left(\chi^{2}=12.246, p=0.016\right)$. Poor sleep and anxiety were not found to be a common problem for associate professors and professors in our study population (Figure 3).

We also checked if anxiety has a relationship with tiredness. Amongst the 14 academicians who felt tired or fatigued every

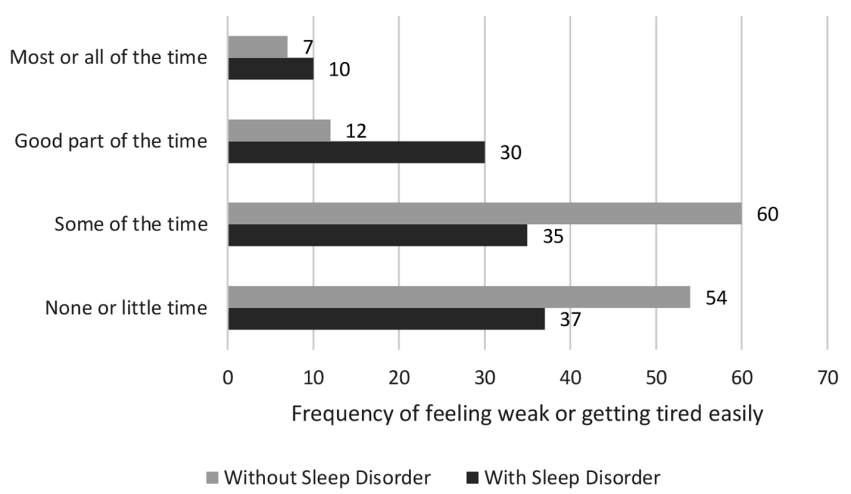

Figure 1. Relationship between having sleeping disorder vs. feeling weak or getting tired easily

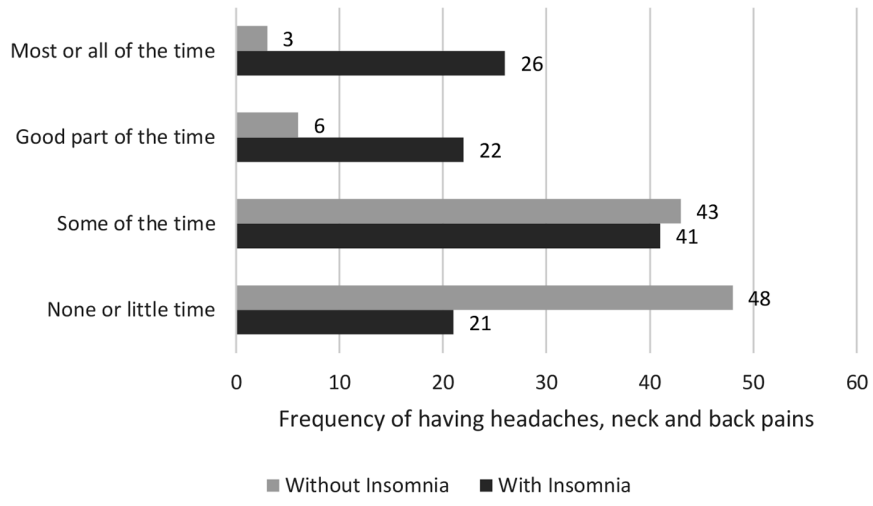

Figure 2. Relationship between insomnia vs. having headaches, neck and back pains day, 9 of them were suffering from anxiety. In addition to this, out of 62 who were tired 3-4 times a week, 43 out of them were suffering from anxiety. From the 49 academicians who were tired 1-2 times a week, 28 suffered from anxiety. The ones who felt tired 1-2 times a month or never were dominated with non-anxiety population which was 63 and 19 respectively (Table 2). These results have suggested a significant relationship between anxiety and feeling tired or fatigued after waking up $\left(\chi^{2}=24.311, \mathrm{p}<0.001\right)$.

The academicians who slept more than 3-4 hours suffered majorly from a sleeping disorder (80\%), and $67 \%$ of the academicians who slept more than 4-5 hours suffered from a sleeping disorder. On the other hand, none of the academicians were found to suffer from a sleeping disorder if they slept more than 9-10 hours or more than 10-11 hours. This is demonstrated in Table 3 and the chi-square test results revealed that this association is not significant $\left(\chi^{2}=16.453, p=0.058\right)$.

Correlation analysis were conducted in order to determine the strength and direction of the relationships between anxiety and sleep disorder, and anxiety and sleep quality. The results have shown a statistically significant correlation $(p=0.008)$ between anxiety and the number of sleep disorders, with a correlation coefficient of $r=0.168$. This result indicates that, as the anxiety level increases, the number of sleep disorders also increases. The correlation analysis between anxiety and sleep quality revealed a negative correlation between these variables, with

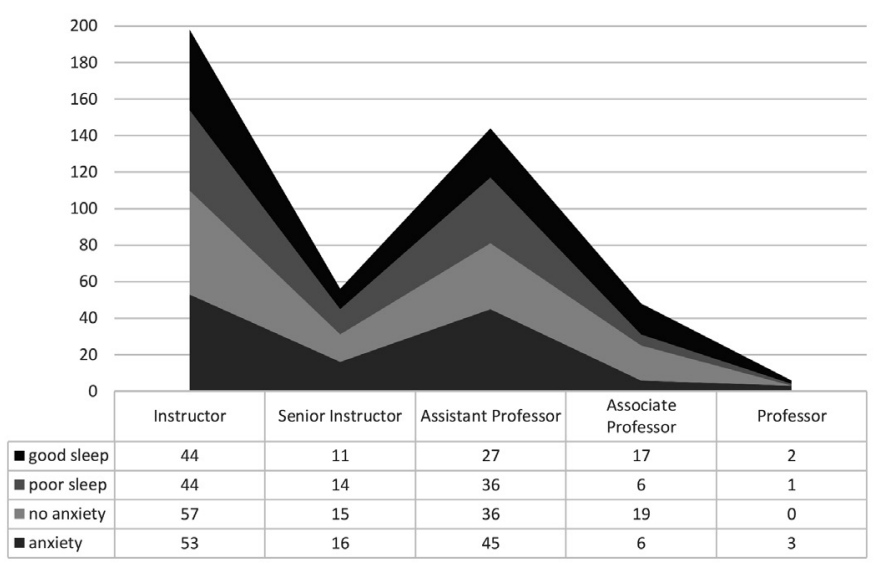

Figure 3. Relationship between academic status vs. having anxiety and sleep quality

Table 2. Anxiety versus feeling tired after waking up

\begin{tabular}{|l|l|l|l|l|l|l|}
\hline & \multicolumn{5}{|c|}{ How often feel tired or fatigued after waking up? } \\
\cline { 2 - 7 } & Nearly everyday & $\mathbf{3 - 4}$ times a week & $\mathbf{1 - 2}$ times a week & $\mathbf{1 - 2}$ times a month & Never & Total \\
\hline Anxiety (-) & 5 & 19 & 21 & 63 & 19 & 127 \\
\hline Anxiety (+) & 9 & 43 & 28 & 31 & 12 & 12 \\
\hline
\end{tabular}

Table 3. Hours of sleep on average each night versus having or not a sleeping disorder

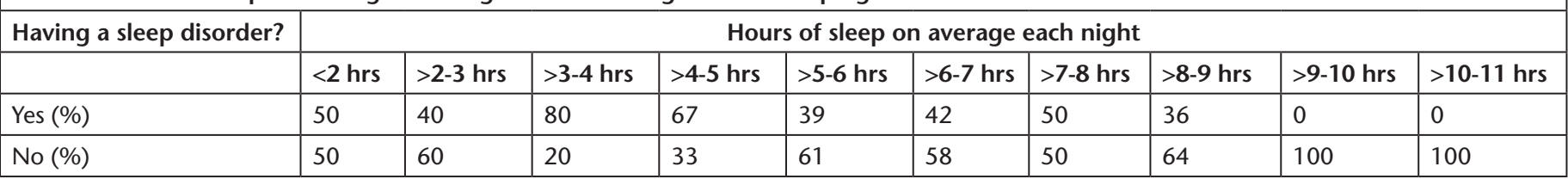


a correlation coefficient of $r=-0.74$. That is, as the anxiety level increases, the sleep quality decreases. However, this correlation was not found significant $(p=0.25)$.

\section{Discussion}

Herein, the results showed that there is a significant relation between anxiety and sleep disorders; while sleep disorders seem to be related with common pain complains and/or tiredness as well. On the other hand, promotion pressure on academics decreases sleep quality and triggers anxiety. Also, tiredness and sleep duration were found to be related with having sleep disorders or anxiety.

It was previously shown that, males have higher levels of anxiety than females (18). Here, our results demonstrated that the percentage of female is higher in anxiety stricken population which was $59 \%(n=73)$ and males were $41 \%(n=50)$. Our finding could be attributed to one of few things: The first being that the study sample had more females with $52.4 \%$, compared to males with $47.6 \%$. Secondly, the sample population was academicians, making this a possible reason for the difference. The third reason explaining the gap between genders could be attributed to the fact that females might have more duties outside their work environment such as taking care of children, cooking or psychological differences.

In our study, most common sleep disorder was insomnia, followed by nightmare, bruxism and sleep apnea respectively and $51.6 \%$ of academicians were suffering from one or more sleep disorder. The rate of insomnia in our study was $20.4 \%$, which is far higher than expected. Also, it is found that there is a significant relationship between insomnia and anxiety. A similar relationship was obtained in a previous research carried out in New Zealand amongst university students (19). Increased insomnia frequency was found to be related with increased depression and anxiety, which is in consistence with the claim that anxiety and depression are the factors resulting in insomnia (8). Similarly; bruxism which was found to be $12.4 \%$ in the general population of academicians, raised to $60 \%$ among anxiety stricken population. A significant relationship between the presence of anxiety disorder and the onset of bruxism is in agreement with our results on bruxism and its relation with anxiety (20).

In our population of academicians with anxiety, rate of sleep apnea were found to be 54\%. Increased severity of sleep apnea is found to be associated with less anxiety and depression (21). On the other hand, there are reports supporting our data by indicating that patients with sleep apnea have more risk for anxiety (22). We think that, study populations are determinant for the sleep apnea and anxiety relationship as Bjorvatn et al. (21) reports the results of a population which have complains referring sleep apnea while in Kaufmann et al.'s (22) study reports the results from a random population.

The rate of last sleep disorder in our study; nightmares was $10.8 \%$ among academicians but $63 \%$ in the anxiety stricken population. The increase of nightmares in anxiety sufferer academicians was in accordance with other sleep disorders. It was reported that $2-5 \%$ of adults have nightmares every week which is lower than our rate in academicians (23). We assume that academicians are a stressful group and that can be the reason behind higher occurrence of nightmares.

In general, our results suggest a significant increase of sleep disorders among academicians suffering from anxiety with a positive correlation. A recent report showed that, anxiety $(45.7 \%)$ is the most common psychiatric condition in people with sleep disorders (24). Similarly, depression which is closely related with anxiety was strongly linked to all sleep problems (25). Broadly; sleep disorders constitute a prominent issue in acute stress and more serious consequences could be brought about by acute stress events in addition to sleep disorders, that's why treatment targeting sleep disorders could alleviate stress symptoms in over $50 \%$ of patients $(26,27)$.

The findings in this research figured out that sleep quality correlates negatively with anxiety level, but without a significant difference. However, both Schoenfeld et al. (28) and Kobayashi and Mellman (29) investigated sleep quality in stressed individuals and found that acute stress would impair sleep quality and even engender sleep disorder which was statistically significant.

Our study revealed that majority of anxious people who suffered from insomnia reported complaints of back and neck pains accompanied by headaches, which is a symptom which could also factor into the worsening of the quality of sleep. This is similar to a proposal by Kobayashi and Mellman (29), that patients with primary insomnia have a greater risk to anxiety on one hand, and anxiety could be a risk factor for chronic insomnia on the other. Another interesting finding of the study was the fact that the majority of the population suffering from anxiety reported feeling tired and de-energized most days of the week, with a lack of drive to accomplish work throughout the week.

The results from this study also showed that, instructors and assistant professors have more anxiety than associate and full professors. This might be relying on the fact that the workload and stress is much higher in instructors and assistant professors. The results of this study lead us to conclude that; close to the half (49\%) of the academicians have anxiety, and there is a significant relationship between anxiety and sleep disorders. Ratio of females having anxiety was higher than males. Insomnia was found to be the most common sleep disorder among the whole population, while nightmares were the most reported sleeping disorder among the anxiety stricken population. Moreover, sleep apnea was the most prevalent sleeping disorder among non-anxious population. Participants with insomnia experienced higher percentage of headache, back pains and neck pains than the ones without insomnia. Also, having a sleeping disorder causes participants to feel week and easily get tired. It has to be noted that, limited number of participants was a limitation of this study which makes it hard to generalize our findings.

A negative correlation was found between anxiety level and sleeping quality. However, this correlation was not statistically significant. Academicians having sleep disorders reported that they have 3-4 hours of sleep on the average, whereas academicians without sleep disorders have 8-9 hours of sleep on the average. 
Another concluding remark is that; anxiety was mostly suffered by instructors and assistant professors rather than associate or full professors.

\section{Conclusion}

As a result, anxiety and quality of sleep are shown to be inseparable, and for more effectiveness academicians need more unstressful work environment. Since anxiety and sleeping disorders cause physical and emotional changes in a bad way, this study is of great significance in providing references for improving sleep quality and manages with anxiety among academicians to improve productivity and quality of teaching.

\section{Ethics}

Ethics Committee Approval: Eastern Mediterranean University Research and Publication Ethics Board with approval number 2016/23-03.

Informed Consent: Participants were informed about the study and their written informed consents were collected prior to protocols.

Peer-review: Internally peer-reviewed.

\section{Authorship Contributions}

Concept: M.G., M.S., Y.B., Design: M.G., M.S., Y.B., K.A., M.M.A., Data Collection or Processing: M.S., Y.B., K.A., M.M.A., N.I.A., Analysis or Interpretation: N.İ.A, M.S., Y.B., K.A., M.M.A., A.A., Literature Search: N.I.A., M.G., A.A., Writing: M.G., N.I.A., A.A.

Conflict of Interest: No conflict of interest was declared by the authors.

Financial Disclosure: The authors declared that this study received no financial support.

\section{References}

1. Schoenborn C, Adams P. Health Behaviors of Adults: United States, 2005-2007. Vital Health Stat 10 2010;1-132.

2. Crocq M-A. A history of anxiety: from Hippocrates to DSM. Dialogues Clin Neurosci [Internet]. 2015 Sep;17(3):319-25. Available from: http://www.ncbi.nlm.nih.gov/pmc/articles/PMC4610616/

3. Labbate LA, Johnson MR, Lydiard RB, Brawman-Mintzer $\mathrm{O}$, Emmanuel N, Crawford M, Kapp R, Ballenger JC. Sleep deprivation in social phobia and generalized anxiety disorder. Biol Psychiatry 1998;43:840-2.

4. Walker MP. Sleep-dependent memory processing. Harv Rev Psychiatry 2008;16:287-98.

5. Cho HJ, Lavretsky H, Olmstead R, Levin MJ, Oxman MN, Irwin MR. Sleep Disturbance and Depression Recurrence in CommunityDwelling Older Adults: A Prospective Study. Am J Psychiatry 2008; 165:1543-50.

6. Sleep Disorders. Anxiety and Depression Association of America. 2016.

7. Bixler EO, Kales A, Soldatos CR, Kales JD, Healey S. Prevalence of sleep disorders in the Los Angeles metropolitan area. Am J Psychiatry 1979; 136:1257-62.

8. Taylor DJ, Lichstein KL, Durrence HH, Reidel BW, Bush AJ. Epidemiology of insomnia, depression, and anxiety. Sleep 2005;28:1457-64.

9. Cifcili S, Ünalan PC, Kıvrak D, Karaca G, Yalçın N, Uzuner A. Frequency and risk factors of sleep problems among high school students who will undergo university entrance exam as a stressful experience. Türkiye Klin Tıp Bilim Derg 2010;30:8-16.
10. Johns MW. Sleepiness in different situations measured by the Epworth Sleepiness Scale. Sleep 1994;17:703-10.

11. Dewald JF, Meijer AM, Oort FJ, Kerkhof GA, Bögels SM. The influence of sleep quality, sleep duration and sleepiness on school performance in children and adolescents: A meta-analytic review. Sleep Med Rev [Internet] 2010;14:179-89.

12. Clemente $M$, Hezomi $H$, Allahverdipour $H$, Jafarabadi MA, Safaian A. Stress and Psychological Well-being: An Explanatory Study of the Iranian Female Adolescents. J Child Adolesc Behav 2016;4:1.

13. Johns MW. A new method for measuring daytime sleepiness: The Epworth sleepiness scale. Sleep 1991;14:540-5.

14. Morin CM, Belleville $G$, Bélanger L, Ivers $H$. The insomnia severity index: Psychometric indicators to detect insomnia cases and evaluate treatment response. Sleep 2011;34:601-8.

15. Shahid A, Wilkinson K, Marcu S, Shapiro CM. Sleep-50 Questionnaire. STOP, THAT and One Hundred Other Sleep Scales. New York, NY: Springer New York; 2011. 319-322 p.

16. Zung WW, Magruder-Habib K, Velez R, Alling W. The comorbidity of anxiety and depression in general medical patients: a longitudinal study. J Clin Psychiatry 1990;51 Suppl:77-80; discussion 81.

17. Berger M, Varvarigou V, Rielly A, Czeisler CA, Malhotra A, Kales $\mathrm{SN}$. Employer-mandated sleep apnea screening and diagnosis in commercial drivers. J Occup Environ Med 2012;54:1017-25.

18. Chandler L. Gender difference and test anxiety. 2006.

19. Samaranayake CB, Arroll B, Fernando AT. Sleep disorders, depression, anxiety and satisfaction with life among young adults: a survey of university students in Auckland, New Zealand. N Z Med J [Internet] 2014; 127:13-22.

20. OLIVEIRA MT de, Bittencourt ST, Marcon K, Destro S, Pereira JR. Sleep bruxism and anxiety level in children. Braz Oral Res 2015;29:1-5.

21. Bjorvatn B, Rajakulendren N, Lehmann S, Pallesen S. Increased severity of obstructive sleep apnea is associated with less anxiety and depression. J Sleep Res 2017.

22. Kaufmann CN, Susukida R, Depp CA. Sleep apnea, psychopathology, and mental health care. Sleep Heal 2017;3:244-9.

23. van Schagen A, Lancee J, Swart M, Spoormaker V, van den Bout J. Nightmare Disorder, Psychopathology Levels, and Coping in a Diverse Psychiatric Sample. J Clin Psychol 2017;73:65-75.

24. Chen Y, Yu E, Liao Z, Tan Y, Qiu Y, Zhu J, Lin S, Wu M. Psychiatric diagnoses and their influencing factors in patients complaining of sleep problems: A study of a psychiatric consultation-liaison service. Int J Psychiatry Med 2018;53(3):197-206.

25. Rossler W, Ajdacic Gross V, Glozier N, Rodgers S, Haker H, Muller M. Sleep disturbances in young and middle-aged adults - Empirical patterns and related factors from an epidemiological survey. Compr Psychiatry 2017;78:83-90.

26. Krakow B, Melendrez D, Pedersen B, Johnston L, Hollifield M, Germain A, Koss M, Warner TD, Schrader R. Complex insomnia: Insomnia and sleep-disordered breathing in a consecutive series of crime victims with nightmares and PTSD. Biol Psychiatry 2001;49:948-53.

27. Spoormaker VI, Montgomery P. Disturbed sleep in post-traumatic stress disorder: Secondary symptom or core feature? Sleep Med Rev 2008; 12:169-84.

28. Schoenfeld FB, Deviva JC, Manber R. Treatment of sleep disturbances in posttraumatic stress disorder: a review. J Rehabil Res Dev 2012;49:729-52.

29. Kobayashi I, Mellman TA. Gender Differences in Sleep During the Aftermath of Trauma and the Development of Posttraumatic Stress Disorder. Behav Sleep Med 2012;10:180-90. 